\title{
Source Determination, Diachronic Regularity, and the Development of Perfects
}

In the preceding chapter, I showed that the expansion of a Preterit in Porteño Spanish and Uruguayan Spanish have received scholarly attention to differing extents. This chapter provides an overview of the existing literature on the diachronic developments of Perfects and, to some extent, Preterits. Section 4.1 offers insights into general theories of the development of perfects and past perfectives, with an emphasis on the various conceptions of grammaticalization clines. Section 4.2 offers an overview of the literature on the Preterit and its expansion and status, with an emphasis on Porteño Spanish and Romance. It is not the purpose of this chapter to question the validity of the observed grammatical trajectories, but rather to question their status as unique diachronic tendencies. As will be shown in the remainder of this book, alternative developments are not marginal, but in the perfect/past perfective domain, such developments occur as often as those referred to as regular, predictable, and typical to Romance.

\subsection{Source Determination and the Development of Perfects}

As we have seen, it is common in historical linguistics to claim that a perfect tends to develop into a past or past perfective. Some authors emphasize how this development is common in Romance languages, such as Dahl (1985: 139), who notes that "it is not uncommon for a PFCT to develop into a PFV. (...) This has happened in a number of Romance languages." ${ }^{1}$ Hengeveld (2011: 592) similarly states that the resultative construction, which originates in the Latin possessive, haber, has evolved into an absolute tense expressing recent past in "most Spanish dialects."

Others go further, claiming that findings from research on particular languages illustrate universal, cross-linguistic paths. Bybee and Dahl (1989: 56), for instance, claim that an "actual diachronic relation can be demonstrated between pairs of grams: a perfect tends to develop into a past or perfective

1 PFCT is Dahl's abbreviation for "perfect," PFv his abbreviation for "perfective." 
as in Romance languages." This means that there is an observed tendency for perfects to develop in certain ways. However, once this development has begun, its further development is taken to be determined; Bybee et al. (1994: 9) argue that "the actual meaning of the construction that enters into grammaticization uniquely determines the path that the grammaticization follows, and consequently, the resulting grammatical meaning." Traugott and Dasher (2002: 3) also ascertain that "the greatest degree of semantic regularity has so far been found in conceptual structures the lexemes of which are typically associated with grammaticalization (...) e.g. (...) aspect, 'have', 'finish."

If a perfect tends to expand and eventually generalize to become a past or past perfective, and subsequently erases the existing past/past perfective category, what then happens to the past/past perfective? It followsimplicitly_that it tends to fall into disuse. This assumption has been put forward in numerous publications (see below for details) but perhaps most explicitly so in the theory of paths (Bybee et al. 1994). As we shall see, most mentions of the past/perfective in this framework and others are implicit assumptions based on the expected trajectories of perfects. A notable exception is Dahl (2004), who, as we saw in the introduction, explicitly argues that the past/past perfective generally is the end point of a development.

The assumption that a trajectory is expected, and that the development of grammaticalizing constructions is predictable, was early treated in detail by Hopper and Traugott (1993) to explain the development from lexical item to grammatical auxiliary. While grammaticalization makes predictions about the development lexical > grammatical (see the discussion on unidirectionality below), the concept of paths involves more specific predictions about the expected developments of construction. This approach to morphosyntactic development — source determination (Bybee et al. 1994: 9-15) — makes predictions of a more specific nature than, for instance, those of the unidirectionality hypothesis. Here, I will not go into detail about the nature of and counterexamples to traditional grammaticalization. I will, however, go into detail about the nature of the paths, a subfield that has been studied and challenged to a lesser extent.

The linguistic paths of development-or clines-were first defined as a "natural pathway among which forms evolve, a kind of linguistic 'slippery slope' which guides the development of forms" (Hopper \& Traugott 1993: 6). Norde (2009: 54-55) points to the fact that in the second edition of the handbook by Hopper and Traugott (2003: 6), the definition of cline was altered, the "slippery slope" was now absent from the picture, and the cline was now conceived as a natural pathway along which forms evolve, a schema which models the development of forms. Note that this definition is more in tune with the 
work of Bybee et al. (1994), in that it implies naturalness to the development along paths.

From the very beginning, the nature of the paths has varied in degree of abstraction. The most abstract path level is exemplified in a precursor to Givón's classic saying “Today's morphology is yesterday's syntax" (Givón 1971: 413), a "meta-cline" (Norde 2009: 55) first described in Givón (1979):

Abstract level:

Discourse $>$ syntax $>$ morphology $>$ morphophonemics $>$ zero

(Givón 1979: 209)

Hopper and Traugott's first descriptions of the clines also varied from descriptions of the abstract level, as observed in the following path:

Less abstract level:

content item $>$ grammatical word $>$ clitic $>$ inflectional affix

(Hopper \& Traugott 2003: 7)

It is also described with more concrete examples, such as in the following clines:

Part of phrase $>$ part of compound $>$ derivational affix A basket full (of eggs) > a cupful of water > hopeful ${ }^{2}$

(Hopper \& Traugott 2003: 7)

Paths of development — of both abstract and concrete nature - play the center role in Bybee et al's influential (1994) work on tense, aspect, and modal categories in the world, also described in 2.3. In the historical linguistics literature, this work provides the empirical and theoretical basis for the source determination hypothesis, and this is where it was first explicitly formulated. The typological base is broad: from a sample of 76 languages from different phyla, the authors identify regularities and commonalities in the meanings expressed by closed-class grammatical morphemes or constructions. Importantly, they also attempt to identify how these similar classes came to be, assuming that grammar is created through usage (recall discussion in Chapter 2). They give examples from categories of both tense, aspect and modality and sum up the

2 Note that the addition of the grammatical terms in line one stems from Norde (2009:54), not from the original source. 
findings as follows (ibid.: 105), in paths of development leading to simple past and perfective grams. This, the perfective path, offers a more concrete level of prediction:

Concrete level:

be, have

come

finish, directionals

$$
\begin{array}{lll}
>\text { resultative } & >\text { anterior } & >\text { perfective/simple past } \\
& >\text { anterior } & >\text { perfective/simple past } \\
>\text { completive } & >\text { anterior } & >\text { perfective/simple past }
\end{array}
$$

One much-studied instance of a path of development is precisely the perfective path, as outlined above. As an empirical basis for this path, Bybee et al. (1994) list the following:

a. The have-Perfect of Romance has developed into past perfective in French.

b. The have-Perfect of Modern Colloquial South German has developed into a simple past, used for, for instance, narration, without any sense of anteriority.

c. In Mandarin, the sentence-final particle le (derived from liao 'to finish') originally had only perfect function but has developed into denoting perfective function and appears directly after the main verb (whether or not the verb is sentence final). According to Hopper and Traugott (2003: 86), it is "clear that the sentence-final function developed earlier than, and gave rise to, the verb-final function, even though they coexist in the language today."

d. In the Dahome dialect of Ewe, the verb 'finish' has developed from anterior into past-tense marker (based on Westermann 1907: 139).

e. In Atchin, the auxiliary ma 'come' merges with pronominal forms to make a past-tense auxiliary. In neighboring varieties, this is still used as anterior.

f. In both Eastern and Western Kru, there exists a Perfect auxiliary that is used as perfective in the Eastern Kru language Lozoua Dida.

Consequently, Bybee et al. (1994: 86) conclude that the "evidence for the passage of anterior to perfective or past is quite strong and distributed across various language families". They also suggest, somewhat surprisingly, based on example (d) above (Ewe), that all pasts and perfectives from sources meaning 'finish' in their material may have gone through an anterior stage, though the "evidence for the anterior stage may be missing" (ibid.). It should be noted 
that Westermann nowhere states that the lexeme meaning 'finish' has ever had anterior function. To have this serve as an illustration of a path appears weakly founded empirically, in addition to being circular: the Ewe case is supposed to count as evidence for a path, while the evidence itself is being reconstructed on the basis of the path it is supposed to instantiate.

Bybee el al. (1994: 104) argue that the evidence from the frequency of occurrence in their data points to the main path of development being that of resultative or completive leading to perfect and then to simple past. Now, if we return to the examples cited by Bybee et al., we find that "the frequency of occurrence" of the resultative path is restricted to Romance (French) and Germanic (South German), while the evidence for the completive path is restricted to Ewe and Mandarin. Note, however, that this development arguably also has occurred in Slavic languages (Östen Dahl, personal communication). It is unclear why this evidence is not included in the empirical support presented by Bybee et al. above. In addition, the evidence from Atchin and Eastern Kru suggests 'come' as lexical source.

It is pertinent here to remember that we have records for only a tiny fraction of language history. It is thus alarming when Romance, one of the most intensely studied of all language families, turns out to show substantial variation in its development of Perfects and Perfectives when studied in detail, as will be shown in 4.3.1.1. What then about other, less studied language families, such as Eastern Kru above? I return to the discussion of whether this empirical basis appears suited to constitute a diachronic universal in Chapter 8 .

\subsubsection{Why the Regularity Postulate in Cognitive Approaches to Grammaticalization?}

Why would linguistic change repeat itself in history? Why are regular pathways of change conceived of as so important in the otherwise flexible usagebased frameworks, with such an emphasis on idiosyncrasy in the synchronic domain?

This formulation appears paradoxical. However, recall from Chapter 2 that grammaticalization may be seen not merely as a diachronic phenomenon but rather as the main creator of grammar. In a sense, this view of emergent grammar (Hopper 1998) is usage-based theory par excellence: grammatical categories arise through processes of use, and the real universals are thus diachronic (Bybee 2008; 2010). Note that in later works, Bybee goes even further and argues that the real universals lie not in the paths but in the mechanisms that create the paths - that is, in domain-general mechanisms such as chunking, harmony, bleaching, and so on (Bybee 2010: 220). In this sense, universals are not linguistic but purely cognitive. 
Bybee (2011: 78) concludes that the mechanisms of change involved in grammaticalization have their basis in processing mechanisms. Since such mechanisms are common to all speakers, they are operating "whenever people are speaking the world over." Therefore, they are universal. Linguistic structure is not universal; mechanisms of change are, and they create common paths of development.

It is important to note here that as the "grammaticalization" term came to be used in different ways (for instance, both for processes that broaden and for processes that tighten a lexeme's scope, for pragmatic bleaching as well as for pragmatic enrichment, etc.; see Chapter 2), the reaction from the grammaticalization community was to widen its field of application, not tighten it (Fischer 2007: 119-120). It is possible that as grammaticalization worked its way from being a description of linguistic change to becoming a framework (Fischer 2007: 61) or theory (see discussion in Faarlund 2008), the importance of the paths became even greater.

The impact of the pathways' regularity can thus be repeated as follows:

- To generate grammatical structure: In a usage-based model, linguistic structure is assumed to arise via use. Because speakers follow the same domaingeneral processes of use (absorption, harmony, frequency, etc.; see also Chapter 2), the same linguistic categories arise in languages from different phyla. The radical expression of this is the idea of an emergent grammar (Hopper 1998).

- To reconstruct prior stages of language: For instance, aspect is assumed to be placed prior to tense in the evolutionary scenario outlined by Heine and Kuteva (2007:110-114), because the meaning of an aspectual category (such as perfect) is assumed to be more specific and less abstract than the highly grammaticalized tense category.

\subsubsection{Grammaticalization: Epiphenomenal?}

In addition to having major synchronic implications, the paths of development also serve as evidence for grammaticalization's being a separate phenomenon-and not an epiphenomenon of independent changes. Recurring pathways are essentially the prime example of the composite nature of grammaticalization because grammaticalization is precisely this, the interaction between otherwise independent processes (Diewald \& Smirnova 2010: 98). Diewald and Smirnova (ibid.: 98) argue that this interaction is why grammaticalization has an explanatory power, which general processes such as analogy and phonological change lack, and see paths as the ultimate example of the unique nature of grammaticalization: 
The distinctive and unique feature of grammaticalization is generally seen in this particular combination and serialization of several processes and stages, which among other things are reflected in grammaticalization scales and paths and complex scenarios of successive contexts and constructions.

This is further illustrated in, for instance, paths that show regular semantic and functional developments (Davidse et al. 2012: 6).

Apparently, this serialization of several processes and stages is necessary for grammaticalization to constitute a unique process. This theoretical motivation may thus have led eager grammaticalization scholars to identify regular paths where the empirical basis is less than impressive. As I have shown, the empiric basis in favor of the perfective path is limited to three Romance languages, colloquial German, and five rather dubious non-Indo-European sources. But according to Bybee et al. (1994), the assumption that certain grammaticalization paths are common in unrelated languages points to the existence of common cognitive and communicative patterns underlying the use of language. As also seen in Chapter 2, this is a crucial claim to cognitive theories of language; it is a claim not about diachrony only but about synchronic states of grammar as well.

It is clear, however, that the primary grammaticalization (the semantic change lexical item > auxiliary; see 2.1.2 for discussion) of the possessive construction has occurred in certain Romance (and other Indo-European) languages; this is not to question the validity of the European examples of the grammaticalization of, for instance, the Latin habere construction. There clearly also is evidence for the path finish $>$ anterior, as well as support for the development possessive > auxiliary (e.g., in the Portuguese verb ter 'to have'; cf. Amaral \& Howe 2009). However, the fact that this is far from the only possible outcome of a competition between perfects and Preterits is overlooked in the literature. Clearly, this competition can motivate both types of expansion. These outcomes will be discussed in the following section.

\subsubsection{Counterexamples}

Identifying counterexamples to the unidirectionality hypothesis is a popular enterprise, and numerous counterexamples have been identified from different phyla and linguistic categories (Janda 2001; Joseph 2011; Norde 2009; 2010 for overview). Here, I am concerned with another type of unidirectionalitynamely, the specific claims of regular paths in the development of tense and aspect, associated with "secondary grammaticalization" (see Chapter 2 for discussion of this term). Recall from section 4.1 that one can distinguish two levels of prediction in grammaticalization theory: the abstract lexical > 
grammatical level, and the more concrete presumed instantiations of these clines, the paths. When it comes to these paths, the most vehement criticism is conceptual rather than empirical and concerns questions about the very nature of unidirectionality, such as questioning whether it is a principle or a hypothesis. Is it a generalization over a strong tendency? Alternatively, is it an inherent feature of grammaticalization, as argued by, for example, Hopper and Traugott (2003)?

It is worth mentioning that when it comes to counterexamples, grammaticalization scholars typically acknowledge their existence but argue that they do not illustrate exact reversals of the grammaticalization processes. Bybee (2011: 77-78) rightly notes that as a grammaticalized form ceases to rise in frequency, such as when English shall decreased in frequency due to the rise of will and be going to, this is not a precise reverse of the process. Note that I agree that decreases in frequency of a grammaticalized form do not constitute a reversal of the grammaticalization path (as argued by Bybee above). So, as we shall see, when the Perfect decreases in frequency in Porteño Spanish, this decrease is not a degrammaticalization. It is not, however, uncommon, which I will stress in the remainder of this work.

Such acknowledgements may be observed-albeit to a lesser extent-in the counterexamples to the paths. As a general tendency, it appears accepted that paths need not come to completion and that they are not compulsory "road maps" (Eckardt 2006: 26). In Traugott and Dasher (2002), we can similarly observe the claim that the largest degree of regularity is found in domains such as aspect (have, finish). They accept, though, that these regularities are not absolute. However, the authors argue that counterexamples are more likely to occur in the nominal domain, since they are more susceptible to extralinguistic factors such as change in the nature or the social construction of the referent. They further argue that microchanges are unique and less predictable but that macrochanges still tend to follow predictable paths. Traugott and Dasher further conclude that one does not expect (or need) $100 \%$ regularity in paths such as these, which are the product of human interaction. But they admit that a large number-say, a quarter of the instances—certainly would discredit the hypothesis. They maintain that until today, the number of counterexamples to semantic unidirectionality would remain small. Similarly, Ariel (2008: 122) states that lexical items being recruited to become grammatical is a more reasonable innovative step than the other way around, that historical changes are virtually always unidirectional, and that these developments are not random or reversible.

However, even though scholars tend to accept the existence of counterexamples, and also tend to accept that unidirectionality may not be more than a statistical tendency, the term "grammaticalization" continues to be used as if 
unidirectionality still were a $100 \%$ reliable feature of it. It appears, then, that despite the massive body of work on counterexamples (see, e.g., Janda 2001), unidirectionality continues to be viewed as a defining criterion of grammaticalization more than as an empirical generalization.

Despite this, however, the insight that regularities are not absolute and that alternative developments may in fact be as common as the expected developments (as we shall see for Latin American Spanish) has been scarcely reflected in the literature. While the literature on unidirectionality and degrammaticalization is vast, the source determination hypothesis has largely remained unchallenged and is rarely counted among the "problem areas" in grammaticalization (see Diewald 2010 for discussion).

There are exceptions; Janda, in a vehement critique of grammaticalization theory (2001), argues that grammaticalization theorists are too preoccupied with fixed grammaticalization pathways as putative guarantees for accurate reconstruction. Reconstruction is a subfield in which pathways of change have been given extensive explanatory load. Observable pathways of change are used to reconstruct prior stages of language. This view has been criticized above all for its obvious circularity; reconstructed pathways serve as evidence for universal pathways, which in turn serve as the basis for further reconstruction (Newmeyer 1998: 279), as is precisely the case in the use of Ewe's putative prior stages, discussed above. Lehmann (2004: 156) similarly states that a case of diachronic variation where an earlier form is reconstructed does not count as historical evidence.

While more conceptual critiques of source determination clearly exist, empirically based path criticisms are more restricted; see, however, Howe (2013), Schwenter and Torres Cacoullos (2008), and Squartini (1998), all of whom discuss Romance, and Romaine (1999), who discusses Tok Pisin.

\subsection{The Diachronic Development of Perfects}

The literature on the perfect and its diachronic development is substantial. Here, a summary of approaches is included because they are relevant to the present case for two reasons. First, they generally ignore the fate of the past/past perfective, but second, they still make strong implicit claims about its development, given the predictions about the Perfect's presumed expansion.

In the reference work World Lexicon of Grammaticalization, Heine and Kuteva (2002) refer to perfect $>$ past and perfect > perfective as two welltraveled grammaticalization paths. For the perfect $>$ past, they list the same examples as do Bybee et al. (1994): colloquial German and Dahome, the latter 
based on the same source that Bybee et al. use, namely, Westermann (1907). As for the perfect > perfective path, this is referred to as a process that has been described "especially by Bybee et al. (1994)" (Heine \& Kuteva 2002: 232). They also maintain that "perfect has given rise to perfective in some European languages" (ibid.: 232), and list (as do Bybee et al.) French as an example of this development. Note that Heine and Kuteva (2002) do not provide other examples than those provided by Bybee et al.

Heine and Kuteva (2006: 140-182) devote a chapter to the rise of possessive Perfects (those referred to as have-Perfects above). They use a number scale $(0-5)$ to place the have-Perfects in terms of their development. The starting point $o$ is the stage in which the have-construction retains its original lexical meaning (of possession), while 5 is the stage in which the possessive perfect is generalized as past time marker. According to their definition, no European languages have yet reached stage 5 , but some have reached stage 4. At this stage, the construction is largely established as marker of past-time reference, with the effect that the old past time marker declines. The authors place Northern Italian and Southern German at this stage. They place French, Standard German, and Standard Italian at stage 3, implying that in these languages, the competition between the have-Perfect and the already existing markers of past is stronger.

It is interesting to note the accounts of the phenomenon in sources written prior to the emergence of the important works on paths of development. What is notable is that in these earlier accounts, the expansion of the perfect seems to be assumed to be restricted to certain European languages, while after the investigations of Bybee and colleagues, the paths are taken to be well traveled and to recur in a number of languages, and are seen as instances of a "diachronic universal."

\subsubsection{Proposed Explanations for the Expansion of a Perfect}

In addition to the general accounts of predictable pathways of change, much has been written on the motivation behind the expansion of a perfect. This section provides an overview of these approaches, judged relevant because they illustrate one possible end point of the competition between a perfect and a perfective. The many approaches to these developments can roughly be divided into two different types, with different arguments: namely, relaxation of degree of recentness and bleaching of the CR component due to frequency. I now discuss these approaches.

\subsubsection{Relaxation of Degree of Recentness Required}

The first approach to be discussed here assumes that a gradual relaxation of the degree of recentness of the perfect makes it expand from being able 
to refer to recent-past context, to gradually being able to refer to hodiernal, later to prehodiernal, and eventually to all past contexts (Comrie 1976). This approach overlaps somewhat with the next line of argumentation, as in Schwenter (1994), who suggests that the perfect can become a past/perfective only after having acquired its "hot news" function (his term for recent past; see 2.2.6) by speakers. This is because this function is the one that most resembles the perfective/past semantically. The expansion of the Perfect in Peninsular Spanish is thus seen to happen not through the relaxation of the semantic scope of the constraints on the perfect but through contexts that are temporally indeterminate.

Some scholars argue that the spread of a perfect constitutes a gradual loss of the semantic relationship with the present moment and a consequent gain of the expression of pure perfective meaning. Klein (1994), for instance, states that recent past is a tense and that this function is presumably where the change from aspect to tense starts in the typical expansion.

According to Dahl (1985), the choice between perfect and simple past is bound up with the information structure in that the probability for using the simple past grows as the time of situation becomes more definite or presupposed. For example, in Swedish, the Perfect is compatible only with indefinite time adverbials. When the Perfect expands, we observe a pattern spread in which the most important semantic element (time of reference) becomes backgrounded.

\subsubsection{Frequency-Induced Bleaching of CR Component}

A somewhat different approach assumes that the perfect expands as the current relevance (CR) component is lost (Bybee et al. 1994: 86-87). In this view, the perfect expands because of how language is used. The idea is that the CR component triggers a more frequent use of the perfect, on the premise that speakers want to express themselves as more relevant (in line with usagebased explanations to language change discussed in Chapter 2). This increased frequency leads speakers to use the perfect in contexts previously not associated with current relevance. This overuse makes the specific semantics bleach, and the CR component eventually disappears. This view is compatible with the idea of semantic bleaching outlined in Chapter 2.

Serrano (1994) similarly argues that the expansion comes about as the speaker wishes to make relevant in the present an action that the Preterit presents as concluded and perfective. Detges (2000) argues that the expansion has to do with the fact that the form that expresses past events with CR eventually loses this feature as it becomes frequently used to refer to events lacking relevance; the use becomes conventionalized and extends to other contexts. Croft 
(2000: 133) relies on pragmatic inference; the past value is viewed as inherent to the perfective marker, and the aspectual value is thus lost.

Common to both accounts above is that they assume that the interaction between the perfect and the past/past perfective, and subsequently the loss of the CR component, are responsible for the expansion of the perfect. These approaches thus presuppose the following: (1) It is the CR component that indirectly triggers the expansion of the perfect, since it is this factor that makes it increase in frequency; (2) this same component is lost precisely because of the increase in its frequency. What is striking, though, is that these approaches appear to assume that the $\mathrm{CR}$ component is lost, not that the perfective past reading is added to the scope of the category. If one assumes that the CR component is lost, the change fits easily into a usage-based picture of frequencydriven semantic change. However, as we shall see in Chapter 7 , it is here assumed that the Porteño Spanish Preterit becomes broader in that it acquires the possibility to express CR but also retains the possibility to express simple perfectivity in the past.

Note that the expansion neither of a perfect nor of a Preterit has been explicitly approached from the viewpoint of historical pragmatics, an approach that has seen a considerable increase during the last decade and that seeks explanations for change in actual context, building on Grices's implicatures, more specifically his assumption that "it may not be impossible for what starts life, so to speak, as a conversational implicature to be conventionalized" (1989:39). The neo-Gricean approach was most explicitly converted into a hypothesis of semantic change in Traugott and Dasher's Invited Inferencing Theory of Semantic Change (IITSC) (2002); it has been refined and employed in various works by Schwenter and Waltereit (2010) and Diewald (2002), to mention two.

\subsubsection{Perfect Spread: An Areal Phenomenon?}

Studies on perfect expansion existed prior to the accounts of similar phenomena that emerged in the 1990s; see, for instance, Heine and Kuteva (2006) for discussion. Oberdeutscher Präteritumschwund (Upper German Preterite Loss), or simply Präteritumschwund refers to a change in the verbal system of southern dialects of German, in which the Preterit tense was lost and replaced by the Perfect, a change often assumed to have occurred around 1500 (Sapp 2009). It is therefore worth mentioning that the Perfect's spread in European languages can also be viewed as an areal phenomenon; that is, the have-Perfects did not arise independently but rather did so because of contact (Heine \& Kuteva 2006). This is based on the geographical distribution of the Perfect on the European mainland. The full expansion of the Perfect has occurred in a geographically continuous area covering parts of France, Germany, and Italy. 
The Perfect/Preterit distinction is retained in certain areas only; this original distribution is sometimes referred to in terms of the Perfect as a "peculiar maritime category" (Lindstedt 2000: 371). This is so because most languages that preserve the distinction are situated on the fringe of the European continent: Baltic Finnic languages, Scandinavian, North Germanic, English, Spanish, Portuguese, Southern Italian, Greek, Albanian, and Macedonian, to mention a few.

This theory reflects the fact that the distribution of grammatical elements such as articles, case markings, tense, and aspect categories are usually highly skewed geographically, suggesting that grammaticalization processes are highly sensitive to contact influence. In addition, this theory draws on the assumption that what is borrowed in grammar is periphrastic constructions and free markers, rather than fused material and affixes. This assumption is consistent with Heine and Kuteva's assumption (2003) that grammatical replication is constrained by grammaticalization principles such as unidirectionality and that the order of borrowing can actually be reconstructed by means of the relative maturity of the borrowed material. Here, I will not go into detail about the discussion of whether the Perfect's spread in mainland Europe is an areal phenomenon.

\subsection{Accounts for Developments of Past/Past Perfective}

In sharp contrast to the vast literature on the perfect within a grammaticalization framework, stand diachronic accounts of the perfective. While the range of proposed explanations for the expansion of a perfect is broad indeed, very little has been written on the past/past perfective's development or on the outcome of its competition with the perfect. Brinton (1988: 15) rightly notes that there has been little debate on the function of the simple past in English. ${ }^{3}$ Note, however, that a number of studies do discuss the historical development of past tenses in Indo-European and the development of past tense forms in, for example, English (Bybee 1995).

As seen above, the massive literature on the perfect's trajectories provides strong implications about the development of pasts/past perfectives; if a perfect tends to expand, it follows that the past/perfective past tends to disappear. To the best of my knowledge, the past/perfective past is not accounted for in

3 But note the existence of Preterit-present verbs; see Fischer (2007: 162-163). 
any approach reminiscent of paths (except as semantic/functional end point of the perfect). Nor do there exist, to my knowledge, any semantic/diachronic models accounting for the further diachronic development of pasts/perfective pasts.

The notion of perfage introduced in 2.2 is relevant to this discussion. The synthetic past/past perfective is old as a gram and typically falls into disuse in competition with an analytical, new construction (Bybee et al. 1994). From the view of source determination, an expanding gram is assumed to bleach semantically parallel to its losing phonological substance. In Porteño Spanish, however, what we observe is an old, synthetic gram that expands semantically and functionally but does not (yet) lose phonological substance.

Viewed synchronically, several accounts within not typologically oriented frameworks do emphasize the competing relationship between perfects and Preterits. Schaden (2009) proposes a formal/pragmatic model to account precisely for the expansion of the Preterit in varieties of English and of Latin American Spanish, while Dickey (2001) suggests that the semantics of the Preterit do indeed include experiential readings. Such matters are discussed in more detail in Chapter 7 .

\subsubsection{Empirical Studies}

Two types of empirical sources will be discussed here. First are those that make explicit reference to the development of perfectives/perfects, and second are language descriptions that illustrate how heterogeneous the perfect/perfective distribution appears to be in Romance. I now turn to the former.

Before continuing, it is important to note that, as noted in 4.1, there clearly has occurred a possessive $>$ perfect development. It will be stressed, though, that this path is not the only end point possible for a past/perfective versus perfect opposition. I shall argue that the real tendency is for a formal opposition between perfect and past/perfective to disappear. Which formal structure survives appears to vary. Apparently, pragmatic and dialogical forces may motivate the survival of both.

Empirical approaches to source determination exist; Squartini (1998), for instance, notes that the development of the Perfect in Brazilian Portuguese does not follow the expected pathways. In this variety, the Preterit is used to convey past with CR, the adverb já 'already' also combines with the Preterit, and the já + Preterit construction may be in a process of grammaticalization (see also Fløgstad 2014 for evidence of a similar process in Porteño Spanish). In addition, Brazilian has a grammaticalized construction expressing past with CR with the lexical source ter 'to have': 


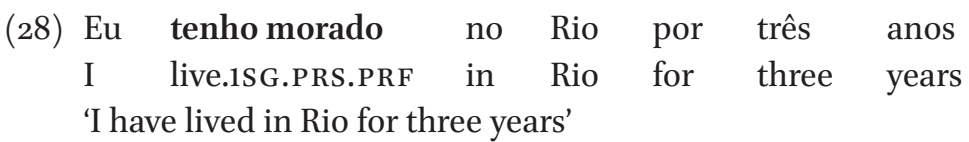

(Howe 2013: 77)

Harris (1982), in a seminal article, notes that "the ultimate stage" (the loss of the past simple paradigm) has been reached by French, Northern Italian, and Rumanian. He nevertheless argues that evidence from other Romance languages is at best suggestive when it comes to whether these varieties will follow the same path. According to Harris, the evidence renders a change in Peninsular Spanish neither imminent nor inevitable.

One tradition, however, typically approaches the Preterit/Perfect distribution in Romance from a variationist, grammaticalization-based point of departure (see, e.g., Rodríguez Louro 2009; Schwenter \& Torres Cacoullos 2008; 2010). These approaches rely largely on assumptions about morphosyntactic change put forward in the grammaticalization framework, and their use of large corpora provides particularly valid evidence. In my view, these approaches to a small extent acknowledge that the behavior of the Perfect in many Latin American varieties stands in sharp contrast to assumptions about regularity and predictability in secondary grammaticalization.

Howe (2013: 7), on the other hand, refers to the perfect > perfective path as "rather problematic" and questions whether the Perfect in Peruvian Spanish is in fact grammaticalizing at all. However, in his approach, he explicitly uses the typical Peninsular development (the perfect $>$ perfective path described in Bybee et al. 1994) as the primary mechanism in his approach to the Peruvian Perfect/Preterit distribution. Howe's study (2013) provides the most extensive account of Perfects and Preterits in Spanish varieties. The following table, from Howe and Rodríguez Louro (2013), provides an overview of the use of Preterit versus Perfect in a CR function in three Spanish varieties:

TABLE 3 Perfect/Preterit distribution in three Spanish varieties, after Howe and Rodríguez Louro (2013: 50)

\begin{tabular}{lll}
\hline & Preterit & Perfect \\
\hline Peninsular Spanish & $46 \%(\mathrm{~N}=827)$ & $54 \%(\mathrm{~N}=956)$ \\
Mexican Spanish & $85 \%(\mathrm{~N}=1903)$ & $15 \%(\mathrm{~N}=331)$ \\
Argentinean Spanish & $94 \%(\mathrm{~N}=783)$ & $6 \%(\mathrm{~N}=47)$ \\
\hline
\end{tabular}


The Argentinean data in Table 3 stem from Rodríguez Louro (2009), and their overall distribution is remarkably similar to that of age group I in this sample, as will be shown in Chapter 6, more specifically, in Table 11.

Kany (1945 [1970]: 198-202) notes that the Preterit is preferred over the Perfect in a majority of Latin American varieties and that frequent Perfect use is restricted to certain Northern Argentinean varieties (as noted above), in addition to Bolivian and Peruvian varieties. Despite the tendency to use the Preterit over the Perfect, he does stress that the distinctions are not rigid. Note, however, that Kany's descriptions are rather schematic, and they ignore, for instance, intralanguage variation as well as subfunction variation. However, his early account provides yet another piece of evidence in favor of the demise of the Perfect in these varieties.

Penny (1991; 2000: 197) notes that the distinction between Preterit and Perfect is not equal in the entire Spanish-speaking world. In the northeast of the Spanish Peninsula, as well as in practically all of Latin America, Penny argues that the Perfect can be used only for situations that can be prolonged into the future (i.e., persistent situations), thus adhering to the so-called "Latin American norm." Several studies treat the Mexican Perfect/Preterit opposition (see, for instance, Schwenter \& Torres Cacoullos 2010), and it has been claimed that the Latin American norm applies in this variety as well, as the Perfect is reserved for imperfective contexts (Squartini \& Bertinetto 2000).

As I demonstrated in 3.3.2.1, it is an established fact that Buenos Aires Spanish uses the Perfect less frequently to express past with CR than do other varieties of Spanish. Note also that in northern parts of Argentina, a tendency opposite of the one found in Buenos Aires is observed; the Perfect is preferred over the Preterit (Vidal de Battini 1966). Summing up, Howe (2013: 55) shows that the Perfect is used less in Argentinean Spanish than in both Mexican Spanish and Peninsular Spanish, in accordance with the numbers presented in this book.

For Uruguayan and Paraguayan Spanish, Henderson (2010) notes that the Perfect is used more frequently in these varieties than in Porteño Spanish. Howe (2013) notes the same tendency for Peruvian Spanish. The Perfect/ Preterit distinction behaves differently in Portuguese than in most Romance varieties (Squartini 1998) and is also argued to constitute a counterexample to the theory of paths (ibid.). In this sense, it constitutes one of the few explicit critiques of the source determination hypothesis.

It appears to be well known that in American English, the simple past is gaining terrain and can, in certain contexts, be used to express past with $\mathrm{CR}$ (Elsness 1997). However, this gain has received surprisingly little attention in 
the grammaticalization literature (but cf. Schaden 2009 for a formal account that explicitly takes American English into account).

\subsubsection{Perfect and Preterit in Other Romance languages}

Table 4 provides a schematic overview of the Perfect/Preterit distinction in a selection of Romance languages and in other Indo-European languages, in total 50 languages, restricted to - available descriptions of the Perfect/Preterit distinction in a selection of European and Latin American languages.

The columns in Table 4 indicate preference for either Perfect or Preterit, or indicate that the opposition is alive. In those languages where there isa preference for either Perfect or Preterit, this preference is further specified in the language-specific description, indicating, for example, an ongoing change ("Expanded") or an already occurred change ("Expanded").

TABLE 4 Perfect/Preterit in a selection of Romance languages

\begin{tabular}{|c|c|c|c|c|c|}
\hline & & $\begin{array}{l}\text { Opposition } \\
\text { alive }^{4}\end{array}$ & $\begin{array}{l}\text { Perfect } \\
\text { preference }\end{array}$ & $\begin{array}{l}\text { Preterit } \\
\text { preference }\end{array}$ & Source \\
\hline & Europe & & & & \\
\hline 1. & Asturian & & & $\begin{array}{l}\text { Expanding } \\
\text { Preterit }\end{array}$ & Penny 2000 \\
\hline 2. & Canarian & & & $\begin{array}{l}\text { Expanding } \\
\text { Preterit }\end{array}$ & Piñero Piñero 2000 \\
\hline 3. & Catalan & & $\begin{array}{l}\text { Expanding } \\
\text { Perfect }\end{array}$ & & Hualde 1992: 304 \\
\hline 4. & $\begin{array}{l}\text { Franco- } \\
\text { Provençal }\end{array}$ & & $\begin{array}{l}\text { Expanding } \\
\text { Perfect }\end{array}$ & & $\begin{array}{l}\text { Squartini \& Bertinetto } \\
2000: 405\end{array}$ \\
\hline 5 & French & & $\begin{array}{l}\text { Perfect has } \\
\text { expanded }\end{array}$ & & Bybee et al. 1994 \\
\hline 6. & Friulian & & $\begin{array}{l}\text { Expanding } \\
\text { Perfect }\end{array}$ & & $\begin{array}{l}\text { Squartini \& Bertinetto } \\
\text { 2000: } 405\end{array}$ \\
\hline $7 \cdot$ & Galician & & & $\begin{array}{l}\text { Expanding } \\
\text { Preterit }\end{array}$ & $\begin{array}{l}\text { Penny 2000; Zamora } \\
\text { Vicente } 1967\end{array}$ \\
\hline 8. & $\begin{array}{l}\text { Northern } \\
\text { Italian }\end{array}$ & & $\begin{array}{l}\text { Expanding } \\
\text { Perfect }\end{array}$ & & Squartini 1998 \\
\hline
\end{tabular}

4 A Perfect/Preterit opposition is taken to be the prototypical distribution found in, e.g., English (Comrie 1976, Chapter 2). 


\begin{tabular}{|c|c|c|c|c|c|}
\hline & & $\begin{array}{l}\text { Opposition } \\
\text { alive }\end{array}$ & $\begin{array}{l}\text { Perfect } \\
\text { preference }\end{array}$ & $\begin{array}{l}\text { Preterit } \\
\text { preference }\end{array}$ & Source \\
\hline 9 . & $\begin{array}{l}\text { Judeo- } \\
\text { Spanish }\end{array}$ & & & $\begin{array}{l}\text { Expanding } \\
\text { Preterit }\end{array}$ & Varol 2008 \\
\hline 10. & Leones & & & $\begin{array}{l}\text { Preterit } \\
\text { preferred } \\
\text { (archaism) }\end{array}$ & $\begin{array}{l}\text { Penny 2000; Zamora } \\
\text { Vicente 1967: } 208\end{array}$ \\
\hline 11. & Lombard & & $\begin{array}{l}\text { Expanding } \\
\text { Perfect }\end{array}$ & & $\begin{array}{l}\text { Squartini \& Bertinetto } \\
\text { 2000: } 405\end{array}$ \\
\hline 12. & Milanese & & $\begin{array}{l}\text { Expanded } \\
\text { Perfect }\end{array}$ & & $\begin{array}{l}\text { Squartini \& Bertinetto } \\
\text { 2000: } 405\end{array}$ \\
\hline 13. & Norman & $\begin{array}{l}\text { Distinction } \\
\text { alive }\end{array}$ & & & Liddicoat 1994 \\
\hline 14. & Occitan & & $\begin{array}{l}\text { Expanding } \\
\text { Perfect }\end{array}$ & & $\begin{array}{l}\text { Harris \& Vincent 1988; } \\
\text { Squartini \& Bertinetto } \\
\text { 2000: } 405\end{array}$ \\
\hline 15 . & Piemontese & & $\begin{array}{l}\text { Expanded } \\
\text { Perfect }\end{array}$ & & $\begin{array}{l}\text { Squartini \& Bertinetto } \\
\text { 2000: } 405\end{array}$ \\
\hline 16. & Portuguese & & & $\begin{array}{l}\text { Expanded } \\
\text { Preterit }\end{array}$ & $\begin{array}{l}\text { Oliveira \& Lopes 1995: } \\
100\end{array}$ \\
\hline 17. & Romanch & & $\begin{array}{l}\text { Expanding } \\
\text { Perfect }\end{array}$ & & $\begin{array}{l}\text { Squartini \& Bertinetto } \\
\text { 2000: } 405\end{array}$ \\
\hline 18. & Romanian & & $\begin{array}{l}\text { Expanding } \\
\text { Perfect }\end{array}$ & & $\begin{array}{l}\text { Daniliuc \& Daniliuc } \\
\text { 2000: } 157\end{array}$ \\
\hline 19. & Sardinian & & $\begin{array}{l}\text { Expanding } \\
\text { Perfect }\end{array}$ & & Jones 1993 \\
\hline 20. & Sicilian & & & $\begin{array}{l}\text { Preterit } \\
\text { preferred } \\
\text { (archaism) }\end{array}$ & $\begin{array}{l}\text { Centineo 1991; Harris } \\
\text { \& Vincent 1988: 301; } \\
\text { Squartini } 1998\end{array}$ \\
\hline 21. & $\begin{array}{l}\text { Standard } \\
\text { Spanish }\end{array}$ & $\begin{array}{l}\text { Distinction } \\
\text { alive }\end{array}$ & $\begin{array}{l}\text { Expanding } \\
\text { Perfect }\end{array}$ & & Comrie 1976 \\
\hline 22. & Venetian & & $\begin{array}{l}\text { Expanding } \\
\text { Perfect }\end{array}$ & & $\begin{array}{l}\text { Squartini \& Bertinetto } \\
\text { 2000: } 405\end{array}$ \\
\hline & Latin America & & & & \\
\hline 23. & $\begin{array}{l}\text { Bolivian } \\
\text { Spanish }\end{array}$ & & $\begin{array}{l}\text { Expanding } \\
\text { Perfect }\end{array}$ & & Kany $1945[1970]: 200$ \\
\hline 24. & $\begin{array}{l}\text { Chilean } \\
\text { Spanish }\end{array}$ & $\begin{array}{l}\text { Distinction } \\
\text { alive }\end{array}$ & & & Henderson 2010 \\
\hline
\end{tabular}


TABLE 4 Perfect/Preterit in a selection of Romance languages (cont.)

\begin{tabular}{|c|c|c|c|c|c|}
\hline & & $\begin{array}{l}\text { Opposition } \\
\text { alive }\end{array}$ & $\begin{array}{l}\text { Perfect } \\
\text { preference }\end{array}$ & $\begin{array}{l}\text { Preterit } \\
\text { preference }\end{array}$ & Source \\
\hline 25 . & $\begin{array}{l}\text { Colombian } \\
\text { Spanish }\end{array}$ & & & $\begin{array}{l}\text { Expanding } \\
\text { Preterit }\end{array}$ & Kany $1945[1970]: 201$ \\
\hline 26. & $\begin{array}{l}\text { Costa Rican } \\
\text { Spanish }\end{array}$ & $\begin{array}{l}\text { Distinction } \\
\text { alive }\end{array}$ & & & Quesada Pacheco 2009 \\
\hline 27. & $\begin{array}{l}\text { Cuban } \\
\text { Spanish }\end{array}$ & & & $\begin{array}{l}\text { Expanding } \\
\text { Preterit }\end{array}$ & Kany 1945 [1970]: 202 \\
\hline 28. & $\begin{array}{l}\text { Ecuadorian } \\
\text { Spanish }\end{array}$ & & & $\begin{array}{l}\text { Expanding } \\
\text { Preterit }\end{array}$ & Kany 1945 [1970]: 201 \\
\hline 29. & $\begin{array}{l}\text { Mexican } \\
\text { Spanish }\end{array}$ & & & $\begin{array}{l}\text { Expanding } \\
\text { Preterit }\end{array}$ & Lope Blanch 1972 \\
\hline 30. & $\begin{array}{l}\text { Panamanian } \\
\text { Spanish }\end{array}$ & & & $\begin{array}{l}\text { Expanding } \\
\text { Preterit }\end{array}$ & Kany 1945 [1970]: 202 \\
\hline 31. & $\begin{array}{l}\text { Paraguayan } \\
\text { Spanish }\end{array}$ & & & $\begin{array}{l}\text { Expanding } \\
\text { Preterit }\end{array}$ & Henderson 2010 \\
\hline 32. & $\begin{array}{l}\text { Peruvian } \\
\text { Spanish }\end{array}$ & $\begin{array}{l}\text { Distinction } \\
\text { alive }\end{array}$ & & & Howe 2013 \\
\hline 33. & $\begin{array}{l}\text { Brazilian } \\
\text { Portuguese }\end{array}$ & & & $\begin{array}{l}\text { Expanded } \\
\text { Preterit }\end{array}$ & $\begin{array}{l}\text { Oliveira \& Lopes 1995: } \\
100\end{array}$ \\
\hline 34. & Portuñol & $\begin{array}{l}\text { Distinction } \\
\text { alive }^{5}\end{array}$ & & & Lipski 2006 \\
\hline 35 . & $\begin{array}{l}\text { Salvadoran } \\
\text { Spanish }\end{array}$ & $\begin{array}{l}\text { Distinction } \\
\text { alive }\end{array}$ & & $\begin{array}{l}\text { Preference } \\
\text { for Preterit } \\
\text { in certain } \\
\text { contexts }\end{array}$ & $\begin{array}{l}\text { Hernández 20o6; Kany } \\
1945[1970]: 202\end{array}$ \\
\hline 36. & Venezuelan & $\begin{array}{l}\text { Distinction } \\
\text { alive }\end{array}$ & & $\begin{array}{l}\text { Preference } \\
\text { for Preterit } \\
\text { in certain } \\
\text { contexts }\end{array}$ & $\begin{array}{l}\text { Kany } 1945[1970] \text { : } \\
\text { 202; Sedano \& } \\
\text { Bentivoglio } 1996\end{array}$ \\
\hline
\end{tabular}

5 Source difficult to interpret. 
What does Table 4 show? Clearly, it illustrates a substantial variation in the distribution of the Perfect and Preterit in a selection of Romance languages. Importantly, the Latin American varieties exhibit a slight preference toward the expansion of the Preterit; of the 14 languages in the sample, the Preterit is used in contexts previously restricted to the Perfect in eight. Seven of the 22 Romance varieties spoken in Europe exhibit a tendency in the same direction.

These findings have important implications. Recall Dahl's claim, quoted in the introduction: "Past tenses and perfectives rarely develop into anything else: they seem to be, in a sense, the stable final point of that development" (2004: 275). In the languages in which the Preterit has expanded, the older, synthetic form - with past-perfective function - has gained terrain. This means that in a competing relationship between a Perfect and a Preterit, it appears impossible to predict which category will expand; both appear as likely to do so. The generalization emerging from this is one I will return to: what tends to disappear is the morphological expression of past with CR. The surviving form varies, as illustrated through this selection of Latin American varieties. The selection of Germanic languages shows less of a tendency toward the expansion of Preterit, as shown in Table 5 .

TABLE 5 Perfect/Preterit in a selection of Germanic languages

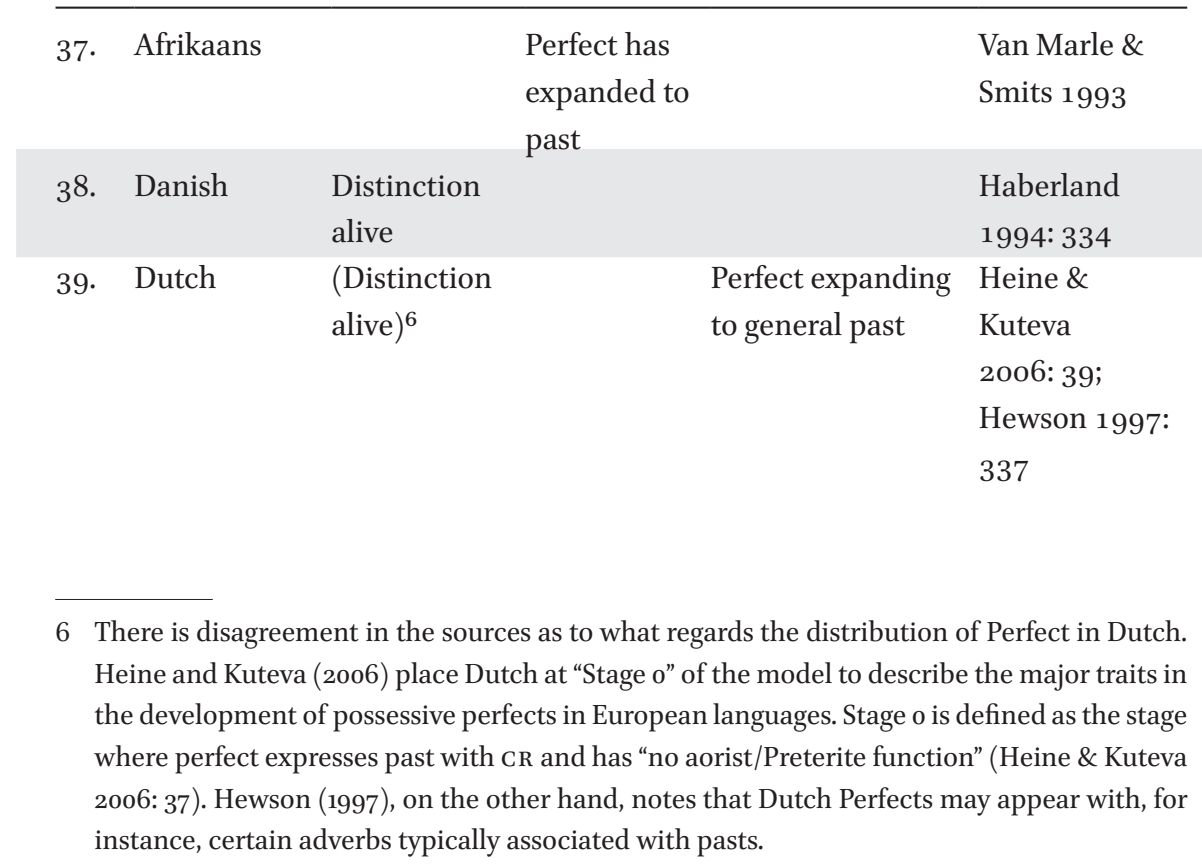


TABLE 5 Perfect/Preterit in a selection of Germanic languages (cont.)

\begin{tabular}{|c|c|c|c|c|c|}
\hline 40. & $\begin{array}{l}\text { American } \\
\text { English }\end{array}$ & & & $\begin{array}{l}\text { Preterit accepted } \\
\text { in certain CR } \\
\text { contexts }\end{array}$ & Elsness 1997 \\
\hline 41. & $\begin{array}{l}\text { British } \\
\text { English }\end{array}$ & $\begin{array}{l}\text { Distinction } \\
\text { alive }\end{array}$ & & & Elsness 1997 \\
\hline 42. & Faroese & $\begin{array}{l}\text { Distinction } \\
\text { alive }\end{array}$ & & & $\begin{array}{l}\text { Thráinsson } \\
\text { et al. } 2004\end{array}$ \\
\hline 43. & Frisian & $\begin{array}{l}\text { Distinction } \\
\text { alive }\end{array}$ & & & Tiersma 1985 \\
\hline 44. & $\begin{array}{l}\text { South } \\
\text { German }\end{array}$ & & $\begin{array}{l}\text { Perfect has } \\
\text { expanded to } \\
\text { past }\end{array}$ & & $\begin{array}{l}\text { Heine \& } \\
\text { Kuteva } \\
\text { 2006: } 37\end{array}$ \\
\hline 45. & $\begin{array}{l}\text { North } \\
\text { German }\end{array}$ & $\begin{array}{l}\text { Distinction } \\
\text { alive, Perfect } \\
\text { entering past } \\
\text { domain }\end{array}$ & & & $\begin{array}{l}\text { Heine \& } \\
\text { Kuteva } \\
\text { 20o6: } 39\end{array}$ \\
\hline 46. & Icelandic & $\begin{array}{l}\text { Distinction } \\
\text { alive }\end{array}$ & & & $\begin{array}{l}\text { Thráinsson } \\
2011\end{array}$ \\
\hline 47 & Norwegian & $\begin{array}{l}\text { Distinction } \\
\text { alive }\end{array}$ & & & $\begin{array}{l}\text { Faarlund et al. } \\
1997\end{array}$ \\
\hline 48. & Swedish & $\begin{array}{l}\text { Distinction } \\
\text { alive }\end{array}$ & & & Larsson 2009 \\
\hline 49. & Yiddish & & $\begin{array}{l}\text { Perfect has } \\
\text { expanded to } \\
\text { past }\end{array}$ & & Jacobs 2005 \\
\hline 50. & $\begin{array}{l}\text { Pennsylvania } \\
\text { German }\end{array}$ & & $\begin{array}{l}\text { Perfect has } \\
\text { expanded to } \\
\text { past }\end{array}$ & & $\begin{array}{l}\text { Van Ness } \\
\text { 1994: } 431\end{array}$ \\
\hline
\end{tabular}

Here, the Preterit is used to express past with CR in one language, and in this language, American English, this is only so for restricted contexts. In this group of languages, the majority preserve the opposition between the two categories. In only four languages (Yiddish, Pennsylvania German, South German, and Afrikaans) has the Perfect expanded to past.

As a general observation, then, we see a substantial variation in the distribution of the Preterit and Perfect in Romance, and particularly so in Latin 
American varieties, in which the Preterit has expanded in a majority of languages. This is not so for the Germanic languages.

It should be noted that several of the cited sources provide very limited detail about the nature of the distinctions in question (they typically ignore the microsteps; see Chapter 7), and these tables clearly are a simplification. Nevertheless, this overview provides a manifestation of the heterogeneous distinction of Preterits and Perfects in what has been thought of as the language family in which the perfect > perfective past development is most common.

\subsection{Summary}

This chapter has provided an overview of the diachronic development of perfects and perfectives. The emphasis has been on directionality, and its prominence as evidence for the complex and serial nature of grammaticalization has been questioned, based on available empirical material. I have pointed to substantial variation in the distribution of perfects/perfectives but also to the paradox that the empirical studies referred to nevertheless have lacked theoretical consideration as real counterexamples to the source determination hypothesis.

The material reviewed has been of two types: descriptions and discussions of Romance and, to some extent, those of languages from other families, making up a total of 50 reviewed languages. The results are striking. In Romance, the competition between Perfect and Preterit clearly enables the expansion of both, with a slight preference for the Preterit in the Latin American varieties. When reviewing the evidence on which the universality of the perfective path is based, one might speculate about how such conclusions could have been drawn on such a small empirical sample. Could the point of departure have been French and other European languages? The fact that the Romance language family exhibits such variation is worrying. What about other, less documented (and studied) language families? 